\title{
Облигационный рынок России: макроэкономические ожидания и современные реалии
}

\author{
Зенкина О.И. ${ }^{26}$
}

Очередная облигащионная конференщиия УРАЛСИБ Кэпитал «Облигащионный рынок России 2012: шаг в будущее» поставила своеобразный рекорд по охвату обсуждаемьх тем. Офищиальная часть конференции занимала всего один день, однако количество глобальных тем было вполне сопоставимо с трехдневным инвестиционным форумом. Эксперты круглых столов - будь то «Облигачионный рынок России: шаг в будущее» или «Будущее облигачионного рынка России: мнение инвесторов» - каждую из заявленных тем обсуждали в комплексе настоящих экономических проблем, с учетом существуюших макроэкономических сценариев развития мировой экономики и текущих изменений, как экономических, так и социально-политических.

\section{$J E L: G 24$}

Ключевые слова: конференции, облигащии, макроэкономика, инвестиции, бизнес, реформы, УРАЛСИБ, инвесторы, эмитенть

Очередная облигационная конференция УРАЛСИБ Кэпитал «Облигационный рынок России», в этом году получившая название «Шаг в будущее», была всецело построена на выражении мнения экспертов и участников рынка относительно текущих вызовов. Если прежде заявленные темы в первую очередь касались перспектив развития рынка долговых инструментов, ожиданий, связанных с изменением политической конъюнктуры в России и появлением новых рыночных реалий, то в этом году доклады были посвящены комплексному рассмотрению текущих проблем. Как известно, долговой рынок является одним из основополагающих для российской экономики, которая, по выражению одного из экспертов, традиционно финансируется за счет долга. По мнению организаторов, подтвержденному рядом публикаций независимых экспертов, сейчас, в условиях глобальной экономической нестабильности и резкого изменения баланса сил в мировой финансовой системе, макроэкономические и регулятивные составляющие при рассмотрении современных тенденций на нем важны как никогда. По каждому из вопросов разгорались дискуссии, в которых круг тем постоянно расширялся: ведь каждый доклад влек за собой ряд вопросов - безусловно, актуальных и важных для рынка - но касающихся других аспектов.

В первую очередь это касалось круглого стола, на котором обсуждались именно макроэкономические темы. Эта традиционная сессия Облигационной конференции, являющаяся, по сути, площадкой для обмена мнениями ведущих экономистов России, для многих участников конференции стала одним из источников смелых макроэкономических предположений и цифр, полученных аналитическим путем.

Первым на круглом столе под названием «Новая модель экономического роста. Макроэкономические параметры развития экономики России» выступил Алексей Девятов, главный экономист УРАЛСИБ Кэпитал. По его мнению, подтвержденному собственным анализом импульсной отдачи, практика вовлечения человеческого капитала и выполнение текущего бюджета идут вразрез с основными рекомендациями, декларированными руководством страны. Доходы от нефтегазового сектора не являются драйвером экономического роста, а высокие цены на нефть более не обеспечивают бюджет в должной мере. Расходы на оборону растут, а на образование и медобслуживание - снижаются. Вместе с тем существует масса способов выполнения бюджета, и при этом снижение

\footnotetext{
${ }^{26}$ Руководитель Дирекции маркетинга УРАЛСИБ Кэпитал.
} 
налогообложения необходимо. Оптимизация затрат, как и институциональные реформы, должна стать одним из приоритетов работы государственных институтов, - заключил Девятов.

Чрезвычайно оптимистичную точку зрения в отношении исполнения этой задачи высказал Серей Гуриев, ректор Российской экономической школы. По его словам, при нынешних темпах развития России понадобится 20-25 лет, чтобы достичь уровня развития Западной Европы. Однако оптимизм экономисту внушает именно недовольство правящей элитой, а также в самой правящей элите: планы объявляются, но не реализуются. С 2010 года программа развития почти не менялась, однако реализована она лишь на треть.

К 2015 году, согласно предвыборным обещаниям, Россия должна быть на 50-м месте по рейтингу doing business. По мнению Гуриева, это очень амбициозное утверждение, так как, по сути, оно является одним из KРI для профильных министерств, имеющим свои сроки достижения. «Российская Федерация - это не единая страна, в ней много регионов с разным инвестиционным рейтингом и бизнес-климатом, - сказал Гуриев. - Есть регионы, которые соответствуют инвестиционному климату в странах со сходным уровнем дохода, некоторым губернаторам удается их построить. И туда, несмотря ни на что, все же идут инвесторы. Есть же регионы с бизнес-климатом, как в Зимбабве. Инвесторов там никогда не было, и, скорее всего, они туда никогда не придут, если не поменять инвестиционный климат глобально».

Оптимизм Гуриева не разделил Евгений Ясин, научный руководитель Национального исследовательского университета «Высшая школа экономики». По его мнению, критерием реализации программы является момент роста. «Если его нет, то обязательства не выполняются, - парировал он. - Доля накоплений в ВВП упала с 35 до 18,5\% в процессе реформ. Все время падали накопления. 20\% сбережений - это показатель США. Если увеличивать эту долю - то за счет чего?» Ясин также был крайне скептичен в отношении декларированных обязательств. По его мнению, чтобы выполнить эти обязательства, рост ВВП должен составлять 7-8\% в год, что в настоящее время нереально и не вызывает ничего, кроме недоверия.

Вместе с тем экономист выразил согласие с точкой зрения Девятова о необходимости институциональных реформ и оптимизации расходов государства: «Почему в России в пять раз дороже построить дорогу, чем в Западной Европе?» Однако вместо дальнейшего обсуждения путей реализации представленного сценария он предложил рассмотреть другой - использование возможностей, которые были упущены государством. В качестве примера Ясин привел те шансы, которые создавались при переходе от плановой экономики к рыночной, и которые были связаны с подъемом деловой активности. Однако для того чтобы настолько подняться в рейтинге, для бизнеса должны быть созданы условия, близкие к идеальным. Только на этой основе, по словам Ясина, возможно взаимное доверие бизнеса и власти и, следовательно, повышение темпов экономического роста хотя бы от 2 до 4\%: «Бизнес боится работать. Уровень дохода от налогов - 20\%, куда больше? Если включить нефтедоходы - будет 35\%. Но нужно менять бизнес-климат. Все должны знать: возможности для работы есть, если не работать - проиграешь».

Круглый стол, посвященный возможным изменениям на российском облигационном рынке с точки зрения инвесторов, был одним из самых ожидаемых для участников конференции. Он проходил под знаком выявления основных источников ухудшения конъюнктуры рынка и потенциальных рисков. Обсуждения ряда тем привели к несколько неожиданным результатам, как, например, будущее евробондов, активно обсуждавшееся представителями государственных структур в ходе бизнес-завтрака, открывшего конференцию. По мнению инвесторов, это скорее политический, нежели рыночный, вопрос, и устранение текущих сложностей при работе с этими инструментами требует от профильных ведомств определенной политической воли.

В целом круглый стол, хотя и не был задуман как интерактивный, проходил под знаком свободного выражения мнения участников. Горячие споры вызвал ряд мнений спикеров об изменении мирового баланса внешних долгов развитых стран, в частности Европы и США. 
Ухудшающееся положение этих стран заставляет нервничать инвесторов по всему миру и резко негативно сказывается на развитии российского рынка долгов.

Еще одной крупной темой, заявленной на круглом столе и также расширенной в ходе дискуссий, стал вопрос об эффективности ЦБ РФ для финансовых структур, участников долгового рынка. В ходе продолжительных споров участники пришли к выводу, что динамика курса валюты и его относительная стабильность являются признаком его эффективности. Участников обсуждений не удивило, что в 2008 году дефолтов в банковском секторе было не так много. Следовательно, банковский сектор можно считать защищенным надзором. «Чем больше мы абсорбируем шоков, тем более крепкой становится система», заключил Дмитрий Дудкин, руководитель дирекции анализа долговых инструментов УРАЛСИБ Кэпитал.

Достаточно бурную дискуссию среди инвесторов вызвал вопрос о судьбе эмитентов третьего эшелона. Очевидный вывод о том, что пул эмитентов будет сужаться, был подкреплен неожиданным единодушием участников рынка во мнении, что для инвесторов это хорошо, по крайней мере, на текущем этапе. Вопрос о том, когда на рынок вернется третий эшелон, потребовал достаточно глубокого экскурса в историю развития рынка долговых инструментов в России, а также анализа среднего по рынку аппетита к риску, динамики его изменения в зависимости от меняющихся макроэкономических показателей. Участники круглого стола сошлись во мнении, что при текущей макроэкономической обстановке это произойдет нескоро.

Конференция завершилась лекцией Нуриэля Рубини, знаменитого экономиста, профессора Нью-Йоркского университета. Г-н Рубини начал свою речь с краткого обзора макроэкономических перспектив современного мира, отметил значительное развитие инновационных технологий и высокотехнологичных проектов во всем мире.

Подробно остановившись на ряде серьезных макроэкономических проблем, г-н Рубини в заключение выразил оптимизм в отношении их урегулирования. Он также отметил, что лишь при возвращении экономических отношений и глобального экономического роста к докризисным уровням возможно перенаправление инвестиционных потоков и развитие принципиально новых инвестиционных стратегий, которые будут ориентированы именно на развитие и освоение инновационных технологий. Пока же только страны с большими экономическими ресурсами могут себе позволить как-то поддерживать это направление. 